\title{
Future Time Perspective and Reduction in Motivation for Recreation Department Students in Turkey
}

\author{
Umit Dogan Ustun (Corresponding author) \\ School of Physical Education and Sports \\ Hatay Mustafa Kemal University, Turkey \\ E-mail: umit.dogan.ustun@gmail.com
}

Received: September 6, 2018 Accepted: October 8, 2018 Published: October 11, 2018

doi:10.5296/jei.v4i2.13618 URL: https://doi.org/10.5296/jei.v4i2.13618

\begin{abstract}
The aim of this study was to explore future time perspective and the reduction in motivation among recreation department students in Turkey. A cross-sectional method was used in the study. The study sample consisted of 258 recreation department students from two different universities. In order to collect data, Turkish versions of Husman and Shell (2008)'s "Future Time Perspective Scale" and Beck, Weissman, Lester, and Trexler (1974)'s "Hopelessness Scale" were used. To evaluate data, the SPSS for Windows 20 package program was used. To analyze the differences between participants' future time perspective and the reduction in motivation, MANOVA and independent samples t-tests were used. Additionally, the Pearson correlation was used to identify correlations. As a result, it can be said that reduction in the motivation forms a barrier to the attainment of future goals and to valuing them. Consequently, reduction in motivation prevents students from achieving distant future goals.
\end{abstract}

Keywords: Future time perspective, Reduction in motivation, Pessimism, Drop out

\section{Introduction}

Researchers suggest that there are three main types of time: psychological, biological, and physical time. Among these time phrases, physical time refers to the time that is determined by the clock and the calendar and continues in a linear process from that which has already come from the past, and goes on to the future (Passing, 2003). Different periods existing in this linear process, which we call past, present, and future, are largely influential in understanding the experiences of individuals (Zimbardo \& Boyd, 1999), which is where future time perspective (FTP) emerges. Although future is about physical time, future time perspective is about psychological time and is mainly described as the effect of the individual's immediate or distant future expectations on the current actions undertaken in 
pursuit of their goals (Simons, Vansteenkiste, Lens, \& Lacante, 2004; Leonardi, 2007; Avci \& Erden, 2013). FTP is one of the main components of one's personal life and is related to how a person looks his/her future, as opposed to the present or past (Brothers, Chui, Diehl, \& Pruchno, 2014). In other words, simply, FTP can be conceptualized as the individuals' mental representation of the future (Walker \& Tracey, 2012).

\subsection{The Study of FTP and Relevant Dimensions}

Future time perspective has always been a topic of interest to the researchers. For example, Lewin (1942) indicated that, when individuals develop and pass from childhood to adolescence, their time perspective shifts from a present orientation to a future orientation (Lewin 1942, cited in Perkins, Scherer, Palmer, \& Talley, 2015). Similarly, Neugarten (1968) argued that in middle age most the adults begin to put emphasis on the time left to live, rather than the time they have already lived (Neugarten, 1968, cited in Brothers et al., 2014).

According to researchers, aspects of time perspective can vary according to social context and culture (Jones, 1994, Zimbardo \& Boyd, 1999); a considerable amount of research indicates that FTP has a multidimensional construct (Zimbardo \& Boyd, 1999; Husmann \& Shell, 2008; Brothers et al., 2014). For example, in their study, Zimbardo and Boyd (1999) defined five types of time perspectives as past positive, past negative, present fatalistic, present hedonistic and future-oriented. According to this conceptualization, only future-oriented perspective reflects an emphasis on the future.

Referring to previous research, Husman and Shell (2008) identified their time perspective in terms of four dimensions of valence, connectedness, extension, and speed. According to this conceptualization, valence is about valuing the future and valuing long-term future goals is an indicator of a strong FTP. Connectedness is a general tendency to make cognitive connections between present activities and future goals. Individuals with a strong FTP, all things being equal, are supposed to make connections between their present activities and future goals. Among these dimensions, extension defined as "how far the individual sets his/her goals for the future." Finally, speed dimension encapsulates how an individual perceives and feels the speed of passing time (De Volder \& Lens, 1982; Gjesme, 1983; Husman \& Lens, 1999; Husman \& Shell, 2008).

\subsection{Future Time Perspectives in Education Research}

Because of its important role in human life, FTP researchers have established a convincing body of evidence to inform understanding of the main characteristics of how individuals consider their personal futures (Hilpert, Husman, Stump, Kim, Chung, \& Duggan, 2012). Future time perspective has been investigated from different facets such as social relationships (Lang \& Carstensen, 2002), education, and hope and life satisfaction (Dwivedi $\&$ Rastogi, 2016). However, among those facets, education appears to be the most investigated. For example, in his study Avci (2013) studied the correlations between university students' future time perspective, the delay of gratification-which refers one's preference for larger and more delayed rewards over smaller rewards that are more immediately available- and self-regulation. He used a quantitative approach from which he 
noted that students have been setting distant future goals and highly value these goals. In their study, Walker and Tracey (2012) investigated the role of FTP in career decision-making for college students, and pointed out that although valence was not significantly related to career decision-making, future time perspective plays a key role in career decision-making for university students. Other educational researchers have focused on the effect of FTP on the academic achievement of university students. For instance, Perkins et al. (2015) reported finding that future time perspective is a predictor of GPA for students in an African American College. Individual differences have also been the concept of FTP studies in an educational context. In their study Üstün, Gümüşgül, Işıı, Demirel, and Harmandar Demirel (2016) investigated FTP among physical education and sports faculty students according to individual differences such as age, gender. According to their findings, female students had significantly higher ratings for the extension dimension than did male students. However, they did not find any significant differences according to age.

\subsection{FTP and Its Effects on Motivation}

The university period is a time when students experience emotional, behavioral, social and physical challenges. Furthermore, the responsibility of finding a suitable job after graduation is also a problem (Dereli \& Kabataş, 2009; Üstün, Dedekoç, Kavalalı, Öztürk, Sapc1, \& Can, 2014). Previous studies have shown that motivation has an effect on students' learning, career decisions and graduation rates (Archambault, Janosz, Morizot, \& Pagani, 2009). In this concept, FTP can have several different outcomes for students' motivation for during their current school activity. Because students not only strive for goals in the present or in the near future, they also pursue goals in the more distant future (Schuitema, Peetsma, \& Van Der Veen, 2014). According to Simons et al. (2004), future time perspective is a cognitive-motivational concept as students with a long FTP can have a different motivation than the students with a short FTP, for future goals are experienced differently by these students.

\subsection{The Development of Recreation Departments in Turkey}

When the concept of recreation was added to the agenda of higher education in Turkey, it was associated with tourism. However, in 2000 the Higher Education Board decided to open recreation departments as a part of school physical education and sports (Zorba, 2008). Recreation departments continue to develop today in both the Faculties of Sports Sciences and of Tourism (Ardahan, 2016, p. 301). Accordingly, the data for 2016-17 featured 27 recreation departments in 24 different universities. Among these departments, four of them were located in Tourism faculties, and the other 23 in Sports faculties. In addition, there were then four masters and one Ph.D. program (Özdemir, 2017).

Recreation department graduates can find jobs in public institutions (the state agency) and the private sector; however, lack of employment openings and assignment criterias create some problems for these new graduates. According to Kozak, Tütüncü, and Kozak (2014), factors such as lack of employment in public and local governments, employment problems arising from sectoral communication, the narrowness of employment areas and problems arising from out-of-area employment in the sector are the main barriers confronted by recreation 
department students when they are seeking suitable posts.

\subsection{Present Study}

In this cross-sectional study, we aimed to investigate changes in future time perspective and in motivation for recreation department students, in the light of the factors mentioned above which may affect these students' future time perspective and their motivation.

\section{Materials and Method of Inquiry}

\subsection{Participants}

The sampling group of the present study consisted of 258 recreation department students from two universities. The first of these two universities is from a city in the south part of Turkey. This university can offer many opportunities for the recreation students because it is in a city which has a sea coast, and sports and tourism sectors are highly developed there. The other university is located in a small city from the west part of Turkey, which offers few opportunities for recreation department students. To avoid ethical issues, we call the first university A and the latter university B.

\subsection{Data Collection Tools}

In the study, in order to analyze future time perspectives of the participants we used Husman and Shell (2008)'s future time perspective scale. The adaptation of the scale for Turkish language and culture done by Avc1 and Erden in 2009 using exploratory factor analyze method. Exploratory factor analysis is a method which is generally used to construct a questionnaire to measure an underlying variable (Field, 2009, p. 628). The Turkish version is a self-report scale consisted of 27 items anchored with five-point Likert-type scale from 1 (completely disagree) to 5 (completely agree) covering the four dimensions: valence (e.g., Long range goals are more important than short-range goals); connectedness (e.g., It's not really important to have future goals for where one wants to be in five or ten years); extension (e.g., August seems like a long way off); and speed (e.g., I always seem to be doing things at the last moment) (Avc1 \& Erden, 2009). Additionally, in order to analyze the reduction in the motivation of the participants, we used Beck, Weissman, Lester, and Trexler (1974)'s hopelessness scale. The Turkish adaptation of this scale had been produced by Durak and Palabıyıkoğlu in 1994. The Turkish version consisted of 20 True/False items; for every item, the response was assigned a score of 0 or 1 . The scale covers three factors: feelings about the future (e.g., I look forward to the future with hope and enthusiasm); loss of motivation (e.g., I may as well give up because I can't make things better for myself); and expectations (e.g., I have enough time to accomplish the things I most want to do) (Durak \& Palabıyıkoğlu, 1994). In the present study, we only used the loss of motivation subscale.

\subsection{Procedure}

The self-reported measures from the participants were collected by the researcher using a face to face approach before the lessons in the selected classes. The participants were informed about the study and completed all scales within 15-20 minutes. Informed consent had been obtained from all participants before any assessments were carried out. 


\subsection{Data Analysis}

In the data analyses, Cronbach's Alpha was first calculated for all the sub-scales of FTP, and Split-Half Reliability for reduction in motivation. Then histograms were plotted to determine the kurtosis and skewness values. As the hypothesis tests, we used MANOVA, Independent samples, and Person Correlation statistical methods at 95\% confidence level.

\section{Results}

Table 1. Future time perspective according to university (MANOVA Results)

\begin{tabular}{|l|l|l|l|l|}
\hline FTP & University & $\mathrm{N}$ & Mean & Std. Deviation \\
\hline \multirow{5}{*}{ connectedness } & $\mathrm{A}$ & 100 & 3.20 & .63 \\
\cline { 2 - 5 } & $\mathrm{B}$ & 158 & 4.12 & .66 \\
\cline { 2 - 5 } & Total & 258 & 3.76 & .79 \\
\hline \multirow{5}{*}{ Valence } & $\mathrm{A}$ & 100 & 3.18 & .54 \\
\cline { 2 - 6 } & $\mathrm{B}$ & 158 & 3.44 & .60 \\
\hline \multirow{5}{*}{ Expeed } & Total & 258 & 3.34 & .59 \\
\hline \multirow{5}{*}{} & $\mathrm{A}$ & 100 & 2.87 & .82 \\
\cline { 2 - 6 } & $\mathrm{B}$ & 158 & 3.26 & .93 \\
\cline { 2 - 5 } & Total & 258 & 3.11 & .91 \\
\hline & $\mathrm{A}$ & 100 & 3.07 & .74 \\
\cline { 2 - 5 } & $\mathrm{B}$ & 158 & 3.07 & .65 \\
\cline { 2 - 5 } & Total & 258 & 3.07 & .68 \\
\hline
\end{tabular}

There was a significant difference between students, when considered jointly, on the variables future time perspective, Wilk's $\lambda=.662, \mathrm{~F}(4,253)=32.26, \mathrm{p}=.000$, partial $\eta 2=.33$. A separate ANOVA conducted for each dependent variable, with each ANOVA evaluated at an alpha level of .012. There was a significant difference between A university students and B university students on connectedness $[\mathrm{F}(1,256)=123.400, \mathrm{p}=.000$, partial $\eta 2=.32]$, valence $[F(1,256)=11.548, p=.001$, partial $\eta 2=.04]$, and speed $[F(1,256)=11.546, p$ $=.001$, partial $\eta 2=.04]$. However, there was not a significant difference on extension.

Table 2. Reduction in motivation according to university (t-test results)

\begin{tabular}{|l|l|l|l|l|l|l|}
\hline & University & $\mathrm{N}$ & Mean & Std. Deviation & $\mathrm{t}$ & $\mathrm{P}$ \\
\hline \multirow{2}{*}{ Reduction in motivation } & $\mathrm{A}$ & 100 & 2.95 & 1.91 & -9.668 & .000 \\
\cline { 2 - 8 } & $\mathrm{B}$ & 158 & 5.16 & 1.57 & & \\
\hline
\end{tabular}


According to analyze results there was a significant difference on the variable reduction in motivation, t.05 $=45.97, \mathrm{p}=.000$.

Table 3. Correlation between FTP and Reduction in Motivation

\begin{tabular}{|l|l|l|l|l|l|}
\hline \multicolumn{2}{|c|}{} & Connectedness & Valence & Speed & Extension \\
\hline \multirow{3}{*}{ Reduction in motivation } & $\mathrm{r}$ & $.574^{* *}$ & $.184^{* *}$ & $.300^{* *}$ & $-.133^{*}$ \\
\cline { 2 - 7 } & $\mathrm{P}$ & .000 & .003 & .000 & .032 \\
\cline { 2 - 7 } & $\mathrm{N}$ & 258 & 258 & 258 & 258 \\
\hline$* \mathrm{p}<.05, * * \mathrm{p}<.01$. & \multicolumn{3}{l}{} \\
\hline
\end{tabular}

According to Pearson Correlation results, there is a positive and high correlation between reduction in motivation and connectedness. In addition, there is a positive but weak correlation between reduction in motivation and valence, moderate and positive correlation between reduction in motivation and speed. Lastly, there is a negative but weak correlation between reduction in motivation and extension.

\section{Discussion}

The purpose of this paper was to analyze future time perspective and reduction in motivation among recreation department students. According to the analyzed, results students from university B had higher points from the future time perspective subscales except the extension sub-dimension, than had students from university A (see Table 1). If we consider the characteristics of these two universities, it may seem surprising that students from a university that located in a smaller city can have strong FTP than the students from the other university. This situation could be explained if these students feel that they must prepare for the future because they do not have many options. The literature contains studies with both similar or different results. For example, Üstün et al. (2016) noted in their study that recreation department students had significantly higher points from the extension sub-scale than did the students from other department. In addition, they added that recreation department students could set more distant future goals than did the other students. In another study, Dallı and Pekel (2017) found that recreation department students had higher points in the connectedness sub-scale than other students. However, this result was found to be insignificant.

The study results also revealed that university B students suffer more from reduction in motivation than did university A students (see Table 2). This result may well be an outcome of the characteristics of the city where university B is located. A city with fewer job opportunities can be a breeding ground for the reduction in motivation. Bridgeland, Dilulio, and Morison (2006) reported that $70 \%$ of high school dropouts occurred because these students were unmotivated. This result is more or less similar for university students (Larsen, Sommersel, \& Larsen, 2013, p. 26). 
Lastly, the analyzed results showed that FTP significantly correlates with the reduction in motivation (see Table 3). According to Schuitema et al. (2014), FTP can have significant consequences for students' motivation for school, because FTP is a cognitive-motivational concept which results from motivational goal setting (Nuttin, 1964). According to the analyzed results, it may be said that the reduction in motivation obstructs connection with future goals and the valuing of them. In addition, a reduction in motivation prevents students from achieving reaching distant future goals.

\section{Conclusion}

In Turkey, the development of recreation departments is a recent development and the number of departments is expanding year by year.Because the learners' future goals can motive these students, it is particularly important to reinforce these students' motivation in the university period. Further studies should also be carried out in order to analyze the effect of FTP on parameters such as the motivation of recreation department students.

\section{References}

Archambault, I., Janosz, M., Morizot, J., \& Pagani, L. (2009). Adolescent behavioral, affective, and cognitive engagement in school: relationship to dropout. J Sch Health, 79(9), 408-415. https://doi.org/10.1111/j.1746-1561.2009.00428.x

Ardahan, F. (2016). Türkiye' de rekreasyon. In F. Ardahan (Ed.), Her yönüyle rekreasyon. Ankara: Detay Yayıncılık.

Avc1, S. (2013). Relations between self-regulation, future time perspective and the delay of gratification in university students. Education, 133(4), 525-537.

Avcı, S., \& Erden, M. (2009). Gelecek zaman algısı ölçeği'nin Türkçe formunun geçerlik ve güvenirlik çalışması. Çukurova Üniversitesi Eğitim Fakültesi Dergisi, 3(37), 1-12.

Avc1, S., \& Erden, M. (2013). Gelecek zaman alg1sı ve akademik alanda arzuların ertelenmesinin öğretmen adaylarının akademik başarıları üzerindeki etkisi. Ahi Evran Üniversitesi Kırşehir Ĕ̆itim Fakültesi Dergisi, 14(1), 389-406.

Beck, A. T., Weissman, A., Lester, D., \& Trexler, L. (1974). The measurement of pessimism: The hopelessness scale. Journal of Consulting and Clinical Psychology, 42, 861-865.

Bridgeland, J. M., DiIulio, J. J., \& Morison, K. B. (2006). The silent epidemic: Perspectives of high school dropouts. Washington, DC: Civic Enterprises.

Brothers, A., Chui, H., Diehl, M., \& Pruchno, R. (2014). Measuring future time perspective across adulthood: Development and evaluation of a brief multidimensional questionnaire. The Gerontologist, 54(6), 1075-1088. https://doi.org/10.1093/geront/gnu076

Dallı, M., \& Pekel, A. (2017). Examination of future time perception levels and time management behaviors of the students in the faculties of sports sciences by certain variables. Journal of Human Sciences, 14(2), 1420-1434. https://doi.org/10.14687/jhs.v14i2.4447

de Volder, M. L., \& Lens, W. (1982). Academic achievement and future time perspective as a 
cognitive-motivational concept. Journal of Personality and Social Psychology, 42(3), 566-571. https://doi.org/10.1037/0022-3514.42.3.566

Dereli, F., \& Kabataş, S. (2009). Determination of hopelessness levels and anxieties for finding job of late class students in Muğla University school of health. Yeni Tip Dergisi, 26, 31-36.

Durak, A., \& Palabıyıkoğlu, R. (1994). Beck umutsuzluk ölçeği geçerlilik çalişması. Kriz Dergisi, 2(2), 311-319.

Dwivedi, A., \& Rastogi, R. (2016). Future time perspective, hope and life satisfaction: A study on emerging Adulthood. Jindal Journal of Business Research, 5(1), 17-25. https://doi.org/10.1177/2278682116673790

Field, A. (2009). Discovering statistics using SPSS. London: Sage Publications Ltd.

Gjesme, T. (1983). On the concept of future time orientation: Considerations of some functions' and measurements' implications. International Journal of Psychology, 18(1-4), 443-461. https://doi.org/10.1080/00207598308247493

Hilpert, J. C., Husman, J., Stump, G. S., Kim, W., Chung, W.-T., \& Duggan, M. A. (2012). Examining students' future time perspective: Pathways to knowledge building. Japanese Psychological Research, 54(3), 229-240. https://doi.org/10.1111/j.1468-5884.2012.00525.x

Husman, J., \& Lens, W. (1999). The role of the future in student motivation. Educational Psychologist, 34(2), 113-125. https://doi.org/10.1207/s15326985ep3402_4

Husman, J., \& Shell, D. F. (2008). Beliefs and perceptions about future: A measurement of future time perspective. Learning and Individual Differences, 18, 166-175. https://doi.org/ 10.1016/j.lindif.2007.08.001.

Jones, J. M. (1994). An exploration of temporality in human behaviour. In R. C. Schank, \& M. R. Lepper (Eds.), Beliefs, reasoning, and decision making (pp. 389-411). Hillsade, NJ: Lawrence Erlbaum Associates Publishing.

Kozak, N., Tütüncü, Ö., \& Kozak, M. (2014). Rekreasyon ve rekreasyon yönetimi programlarının amaçları ne olmalı? Akademik Turizm Eğitimi Arama Konferans Sonuç Raporu, İstanbul: Aktif Matbaa.

Lang, F. R., \& Carstensen, L. L. (2002). Time counts: Future time perspective, goals, and social relationships. Psychology and Aging, 17(1), 125-139.

Larsen, M. R., Sommersel, H. B., \& Larsen, M. S. (2013). Evidence on dropout phenomena at universities. Tuborgve, Copenhagen: Danish Clearinghouse for Educational Research.

Leonardi, A. (2007). Future time perspective, possible selves, and academic achievement. New Directions for Adult and Continuing Education, 114, 17-26. https://doi.org/10.1002/ ace. 253

Nuttin, J. R. (1964). The future time perspective in human motivation and learning. Acta 
Psychologica, 23, 60-82. https://doi.org/10.1016/0001-6918(64)90075-7

Özdemir, A. S. (2017). Rekreasyon uzmanlığı. In Karaküçük, S, Kaya, S., \& Akgül B. M. (Eds.), Rekreasyon bilimi 2 (pp. 392-393). Ankara: Gazi Kitabevi.

Passing, D. (2003). Future time span as a cognitive skill in future studies. Futures Research Quarterly, 19(4), 27-47.

Perkins, P., Scherer, S., Palmer, K., \& Talley, C. (2015). Do time perspective and year in school influence GPA in African American college students? American Journal of Educational Studies, 7(1), 65-72.

Schuitema, J., Peetsma, T., \& van der Veen, I. (2014). Enhancing student motivation: A longitudinal intervention study based on future time perspective theory. The Journal of Educational Research, 107(6), 467-481. https://doi.org/10.1080/00220671.2013.836467

Simons, J., Vansteenkiste, M., Lens, W., \& Lacante, M. (2004). Placing motivation and future time perspective theory in a temporal perspective. Educational Psychology Review, 16(2), 121- 139.

Üstün, G., Dedekoç, S., Kavalalı, T., Öztürk, F., Şapçı, Y., \& Can, S. (2014). Üniversite son sınıf öğrencilerinin iş bulmaya ilişkin umutsuzluk düzeylerinin incelenmesi. Amasya Üniversitesi Ĕ̌itim Fakültesi Dergisi, 3(2), 200-221.

Üstün, Ü. D., Gümüşgül, O., Işık, U., Demirel, M., \& Harmandar Demirel, D. (2016). Gelecek zaman algısı: Beden eğitimi ve spor yüksekokulu öğrencilerine yönelik bir çalışma. İ̈ Spor Bilimleri Dergisi, 6(1), 10-20.

Walker, T. L., \& Tracey, T. J. G. (2012). The role of future time perspective in career decisionmaking. Journal of Vocational Behavior, 81, 150-158.

Zimbardo, P. G., \& Boyd, J. N. (1999). Putting time in perspective: A valid, reliable individual differences-metric. Journal of Personality and Social Psychology, 77(6), 1271-1288.

Zorba, E. (2008). Türkiye’ de rekreasyona bakış açısı ve gelişimi. Gazi Haber Dergisi, 52-55.

\section{Copyright Disclaimer}

Copyright for this article is retained by the author(s), with first publication rights granted to the journal.

This is an open-access article distributed under the terms and conditions of the Creative Commons Attribution license (http://creativecommons.org/licenses/by/3.0/). 